\title{
MANAGEMENT OF SOLID WASTE FROM GOVERNMENT HEALTH CENTERS IN THE SOUTHERN ANDAMAN COAST OF THAILAND
}

\author{
SINEENART PUANGMANEE \& MOLTIYA JEARANAI \\ Environmental Science, Faculty of Science and Technology, Phuket Rajabhat University, Thailand.
}

\begin{abstract}
Solid waste (SW) management at government health centers (GHCs) is necessary to reduce pollution, especially in the rural areas. Although, the government health centers have guidelines to control and manage solid waste, some areas are weakly regulated and poorly managed. Government health centers in the countryside are far from waste management and disposal technology. This paper reports on the solid waste management at six government health centers along the Southern Andaman Coast of Thailand and aimed to study the types and quantities of waste storage, collection, transportation, and disposal. The results found that solid waste was separated into non-hazardous waste (NHW, general and domestic waste) and hazardous waste (HW, infectious waste and hazardous waste). The percentages of domestic waste and general waste were $90 \%$ and $10 \%$, respectively. The percentages of infectious waste and hazardous waste were $91 \%$ and $9 \%$, respectively. Moreover, the rates of general and domestic waste from all government health centers were 0.01 and $0.04-1.30 \mathrm{~kg} / \mathrm{person} / \mathrm{day}$, respectively. The average rates of hazardous waste and infectious waste produced were $0.02 \mathrm{~kg} / \mathrm{person} /$ day and $0.01-0.09 \mathrm{~kg} / \mathrm{person} / \mathrm{day}$, respectively. Nonhazardous waste was kept in black or translucent plastic bags inside plastic or stainless-steel or rubber bins. Hazardous waste was usually put in black plastic bags inside a plastic bin and sometimes no plastic bag was used. Infectious waste was kept in red plastic bags inside plastic or stainless-steel bins. Infectious sharp waste was put in yellow or red sharps bins or puncture proof containers without covers. Expired drugs were put in plastic baskets without bags. On-site waste collection was performed by staff personnel at each government health center and off-site disposal of non-hazardous waste was collected by employees of subadministrative organizations that moved waste for disposal by municipal truck to open dumps. Hazardous waste including infectious waste and expired drugs was transported from a district hospital by pickup truck. Infectious waste was later sent for incineration and expired drugs were returned to the suppliers. The transport workers wore unsuitable clothes. Although the waste materials were basically controlled and managed by the guidelines, handling of the waste was incorrect and ineffective. Therefore, solid waste management from top-down needs to strictly practice the guidelines according to the laws for a better environment.

Keywords: management, solid waste, government, health center.
\end{abstract}

\section{INTRODUCTION}

Solid waste (SW) is a problem that contributes to environmental pollution. The sources of solid waste are various and one of these is health care facilities. Health care establishments include hospitals, clinics, medical laboratories, pharmacies, and any support service in the field of medicine [1]. In Thailand, government health centers (GHCs) provide primary health care in the rural areas. The government health centers provide medical treatment, health promotion, disease prevention, and rehabilitation for outpatients only for a population of about 5,000 inhabitants in a village or district [2]. The services and activities of the government health centers for treated and untreated outpatients and visitors produce substantial amounts of solid waste. Sometimes the solid waste from health centers is termed 'health care waste', and the health center is a major source of health care waste. The types of solid waste at government health centers are comprised of non-hazardous waste (NHW, domestic waste) (about 85\%), hazardous waste (HW, about 5\%), and infectious waste (about 10\%) [3]. Poor management of these waste products can cause serious disease in waste handlers, patients, and the general public, and the waste products pollute the environment [4]. Generally, the government health centers have guidelines and are regulated by law, but some 
government health centers have poor management due to lack of awareness and knowledge, weak control or no control by the government and mismanagement according to the guidelines. If the management and control are ineffective, the produced waste residues may find their way into the environment with the possible distribution of pathogens and hazardous chemical materials. Thus, this research aimed to study solid waste management from six government health centers in a medium-sized group in terms of waste type and quantity, waste storage, waste collection, transportation, and waste disposal in a rural area along the Southern Andaman Coast of Thailand.

\section{METHODOLOGY}

\subsection{Study sites}

The site visit survey included government health centers under the Ministry of Public Health of the government of Thailand. The government health centers are located and serviced in a rural area along the Southern Andaman Coast of Thailand (Fig. 1).

The target government health centers in this survey were six government health centers in the medium size group. The characteristics of the government health centers are shown in Table 1. This study collected quantitative and qualitative data between June and August 2017.

\subsection{Survey Methods}

\subsubsection{Surveys and interviews}

Surveys and interviews were conducted by physical checks with the workers responsible for the handling of solid waste to study waste type and quantity, waste storage, waste collection,

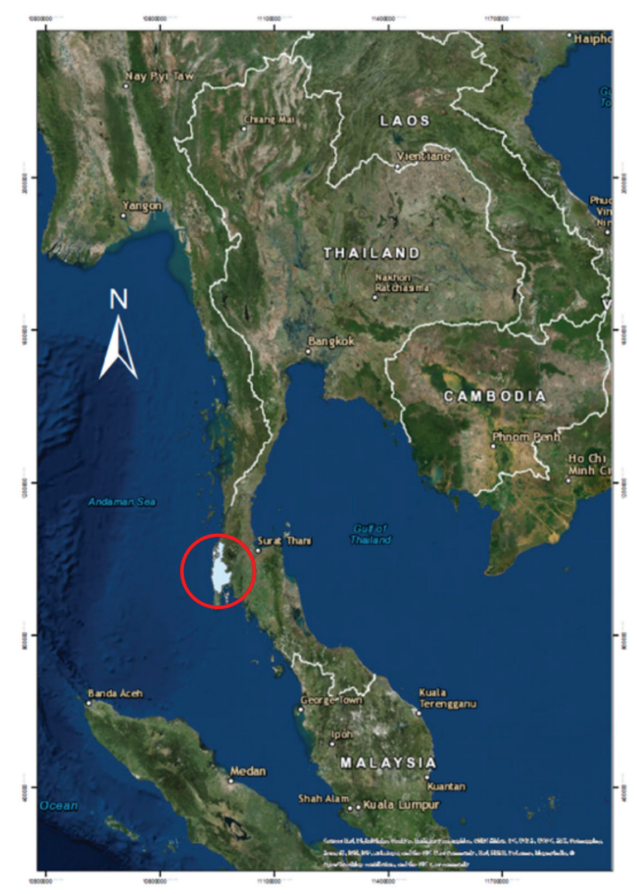

Figure 1: Location site of the study in a rural area along the Southern Andaman Coast of Thailand. 
Table 1: Characteristics of six government health centers (GHCs).

\begin{tabular}{lccc}
$\begin{array}{l}\text { GHCs } \\
\text { (medium size) }\end{array}$ & $\begin{array}{c}\text { Number of users } \\
\text { (approximate data) }\end{array}$ & $\begin{array}{c}\text { Number of villages } \\
\text { within the service area }\end{array}$ & Services \\
\hline GHC 1 & 5,800 & 6 & Antenatal care, \\
GHC 2 & 5,400 & 4 & Vaccination, \\
GHC 3 & 4,800 & 8 & $\begin{array}{c}\text { Family planning, } \\
\text { Non-communicable } \\
\text { disease clinic }\end{array}$ \\
GHC 4 & 4,400 & 9 & \\
GHC 5 & 3,800 & 4 & \\
GHC 6 & 3,300 & 6 & \\
\hline
\end{tabular}

Source: Modified from Phangnga Provincial Public Heath Office, 2016.

transportation, and waste disposal. Solid waste characterization was undertaken by creating specific waste categories developed and modified from the safe management of waste from health-care activities and management of health-care waste at primary health-care centers: a decision-making guide based on World Health Organization 2005 and 2017, respectively $[3,4]$. For the interviews, a template and observation checklist (record form) were developed and modified to support the survey results.

The workers in our study at each government health center were those who were directly delegated to manage the solid waste. The number of interviewed workers was a total of 8 who had three areas of responsibility. The first area of responsibility consisted of six professional registered nurses who controlled and managed the waste at each of the six government health centers. The second area of responsibility was a delegate from all government health centers in a rural area. This worker was an experienced technical nurse. The last person was a representative from a district hospital who was responsible for control of infectious waste from all government health centers in the rural area.

\subsubsection{The sampling frame}

The types and quantities of solid waste included all solid waste produced by treated and untreated outpatients and the office buildings related to visitor activities and employees from all services and activities within each government health center. They were studied by sort segregation and the solid waste was weighed once a week in two types of solid waste at each government health center: non-hazardous waste and hazardous waste. The quantity and waste rates of the solid waste are presented in terms of $\mathrm{kg} / \mathrm{week}, \mathrm{kg} /$ person/day, and percentage of waste type.

\section{RESULTS AND DISCUSSION}

\subsection{Waste type and quantity}

The types of solid waste at the government health centers are shown in the flow chart (Fig. 2). The waste types were classified into two major groups: non-hazardous waste and hazardous waste. The non-hazardous waste was comprised of general waste and domestic waste from the treated patients (TPs), office buildings (OBs), and untreated patients (UTPs). Hazardous waste included waste products from the untreated patients, office buildings, infectious waste from treated patients, and hazardous waste materials from treated patients that were contaminated with toxic substances and pathogens. Table 2 lists the types of solid waste produced by the six government health centers.

The rates of solid waste produced in terms of average $\mathrm{kg} / \mathrm{week}$ for each type of waste are shown in Table 3. It was found that the greatest and lowest rates of waste produced were at GHC 1 (49.71 


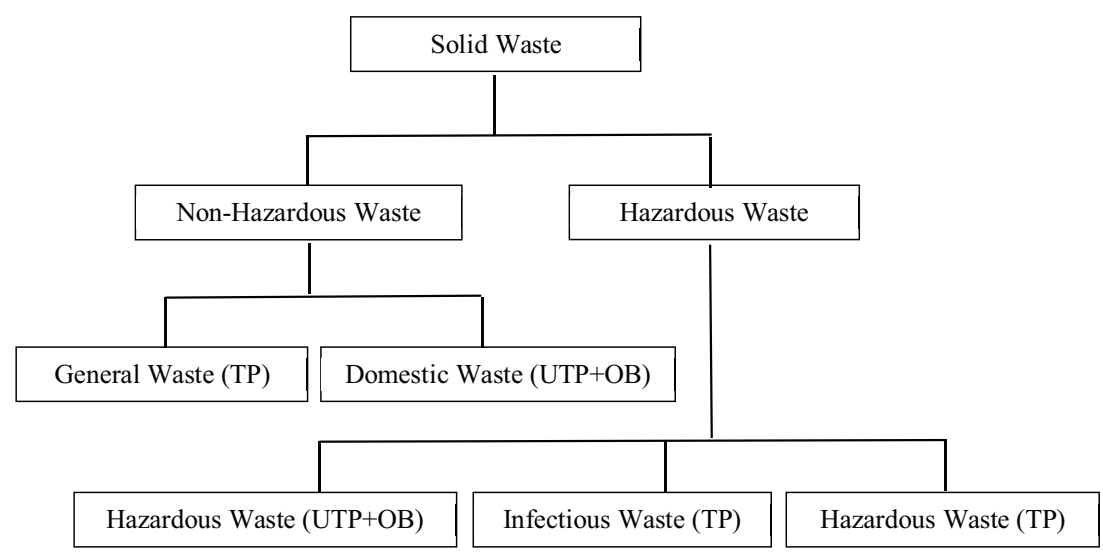

Figure 2: Types of solid waste materials at the government health centers.

$\mathrm{kg} /$ week) and GHC 5 (18.00 kg/week), respectively. The total rate of solid waste produced was $181.83 \mathrm{~kg} /$ week. In addition, the rates of domestic waste produced from office buildings and untreated patients had a maximum rate of $107.39 \mathrm{~kg} / \mathrm{week}$. Infectious waste and hazardous waste from treated patients were produced at rates of $57.52 \mathrm{~kg} /$ week and $1.30 \mathrm{~kg} / \mathrm{week}$, respectively. Moreover, the rates of general and domestic non-hazardous waste produced based on the average

Table 2: Waste types at the government health centers.

\begin{tabular}{|c|c|}
\hline Waste types & Description \\
\hline 1. Non-hazardous waste & $\begin{array}{l}\text { This category consists of SW products that are general } \\
\text { waste and domestic waste from TPs, OBs and UTPs. }\end{array}$ \\
\hline 1.1. General waste (TP) & $\begin{array}{l}\text { General waste includes packages and wrappings of medical } \\
\text { supplies and other equipment (unpacked and unwrapped } \\
\text { before use to treat patients and are uncontaminated. }\end{array}$ \\
\hline $\begin{array}{l}\text { 1.2. Domestic waste } \\
(\mathrm{UTP}+\mathrm{OB})\end{array}$ & $\begin{array}{l}\text { Domestic waste comprises paper, plastic containers, plastic } \\
\text { bags, and compostable waste (food, fruit, and vegetables) }\end{array}$ \\
\hline 2. Hazardous waste & $\begin{array}{l}\text { This category includes hazardous waste from UTPs and } \\
\text { OBs, infectious waste from TPs and hazardous waste from } \\
\text { TPs contaminated with toxic substances and pathogens. }\end{array}$ \\
\hline $\begin{array}{l}\text { 2.1. Hazardous waste } \\
(\mathrm{UTP}+\mathrm{OB})\end{array}$ & $\begin{array}{l}\text { This category includes toxic waste such as aerosol spray } \\
\text { cans, desiccants, glue, batteries, electric light bulbs, and } \\
\text { fluorescent lamps. }\end{array}$ \\
\hline $\begin{array}{l}\text { 2.2. Infectious waste } \\
\text { (TP) }\end{array}$ & $\begin{array}{l}\text { This category includes all waste contaminated with } \\
\text { pathogens. }\end{array}$ \\
\hline $\begin{array}{l}\text { 2.3. Hazardous waste } \\
\text { (TP) }\end{array}$ & $\begin{array}{l}\text { This category includes waste with toxic chemicals such as } \\
\text { expired drugs, broken equipment, but does not cover used } \\
\text { infectious medical supplies (e.g., clinical thermometers), } \\
\text { and uninfected sharp objects. }\end{array}$ \\
\hline
\end{tabular}

Abbreviations: SW, solid waste; TP, treated patient; UTP, untreated patient; OB, office building. 
Table 3: Rates of solid waste produced at the government health centers.

\begin{tabular}{|c|c|c|c|c|c|c|}
\hline \multirow{3}{*}{ GHCs } & \multicolumn{5}{|c|}{ Types of waste (average kg/week) } & \multirow{3}{*}{ Total } \\
\hline & \multicolumn{2}{|c|}{$\begin{array}{l}\text { Non-hazardous } \\
\text { waste }\end{array}$} & \multicolumn{3}{|c|}{ Hazardous waste } & \\
\hline & $\begin{array}{l}\text { General } \\
\text { waste }\end{array}$ & $\begin{array}{l}\text { Domestic } \\
\text { waste }\end{array}$ & $\begin{array}{l}\text { Hazardous } \\
\text { waste }\end{array}$ & $\begin{array}{l}\text { Infectious } \\
\text { waste }\end{array}$ & $\begin{array}{l}\text { Hazard- } \\
\text { ous waste }\end{array}$ & \\
\hline GHC 1 & 2.30 & 15.81 & 0.00 & 31.30 & 0.30 & 49.71 \\
\hline GHC 2 & 2.30 & 13.15 & 0.10 & 2.72 & 0.10 & 18.37 \\
\hline GHC 3 & 2.00 & 11.96 & 3.90 & 11.90 & 0.10 & 29.86 \\
\hline GHC 4 & 1.02 & 29.87 & 0.00 & 3.60 & 0.00 & 34.49 \\
\hline GHC 5 & 2.40 & 11.20 & 0.00 & 4.30 & 0.10 & 18.00 \\
\hline GHC 6 & 1.50 & 25.40 & 0.10 & 3.70 & 0.70 & 31.40 \\
\hline Total & 11.52 & 107.39 & 4.10 & 57.52 & 1.30 & 181.83 \\
\hline
\end{tabular}

per person from all government health centers were 0.01 and $0.04-1.30 \mathrm{~kg} / \mathrm{person} / \mathrm{day}$, respectively. The rates of hazardous waste (UTP and OB), infectious waste, and hazardous waste (TP) were $0.02 \mathrm{~kg} /$ person/day, $0.01-0.09 \mathrm{~kg} /$ person/day, and $<0.10 \mathrm{~kg} /$ person/day, respectively. The results reported by Diaz et al. [5] were similar in that the clinical waste (infectious waste) from outpatients generated at a source in a provincial hospital in Vietnam averaged $0.005 \mathrm{~kg} /$ patients-day).

In addition, in the group of non-hazardous materials, the percentage of domestic waste (UTP+OB) was high at $90 \%$ and general waste (TP) was at $10 \%$. The cause of the high percentage was because the waste materials came from two sources (waste from UTP+OB). Furthermore, the domestic waste (UTP+OB) was mixed with hazardous waste (UTP+OB). In addition, general waste (TP) was also from the relatives of patients who came into government health centers but were not treated or they were not treated because they came into the government health centers to receive only prescribed drugs and for other activities unrelated to the treated patients (visitor activities) [6]. Although the volume of hazardous waste (TP) that resulted from expired drugs was the lowest in the group, it is important for management and disposal because they were toxic and dangerous when they contaminate the environment. Therefore, the government health centers tried to reduce the volume of expired drugs by returning them to the supplier or transferring nearly expired drugs to other government health centers [7]. The details are shown in Fig. 3.

Moreover, in the group of hazardous waste it was found that the percentage of infectious waste had a maximum of $91 \%$, hazardous waste $(\mathrm{UTP}+\mathrm{OB})$ was $7 \%$, and hazardous waste (TP) was $2 \%$. The results are shown in Fig. 4.

\subsection{Waste storage}

All solid waste materials produced within each government health center from all services and activities were stored and collected by staff personnel at the government health center under the control of professional registered nurses. The storage of solid waste was classified into two major types: non-hazardous waste and hazardous waste.

Non-hazardous waste included general waste from the treated patients and domestic waste from the office buildings and untreated patients. All waste products were put into closed 


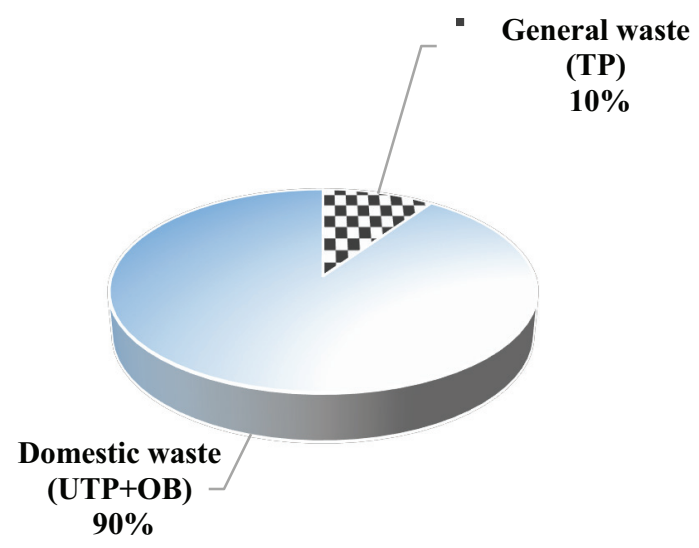

- General waste (TP) Domestic waste (UTP+OB)

Figure 3: Percentage composition of non-hazardous waste.

containers that had a black or translucent plastic bag inside a plastic or stainless-steel bin. The results of this study on the plastic bins and black plastic bags were similar to these other reports: (1) hospital solid waste management practices in Limpopo Province, South Africa [8]; (2) a case study in two hospitals on hazardous health care waste management in the Kingdom of Bahrain [1] and health care waste collection and segregation systems and health care waste management in Cameroon [9]; (3) a case study from the Southwestern Region on health care waste management in Botswana [10]; and (4) storage, collection, treatment and disposal system [10].

Hazardous waste included hazardous materials from office buildings, untreated patients, and treated patients. These waste materials were usually put into black or white bags

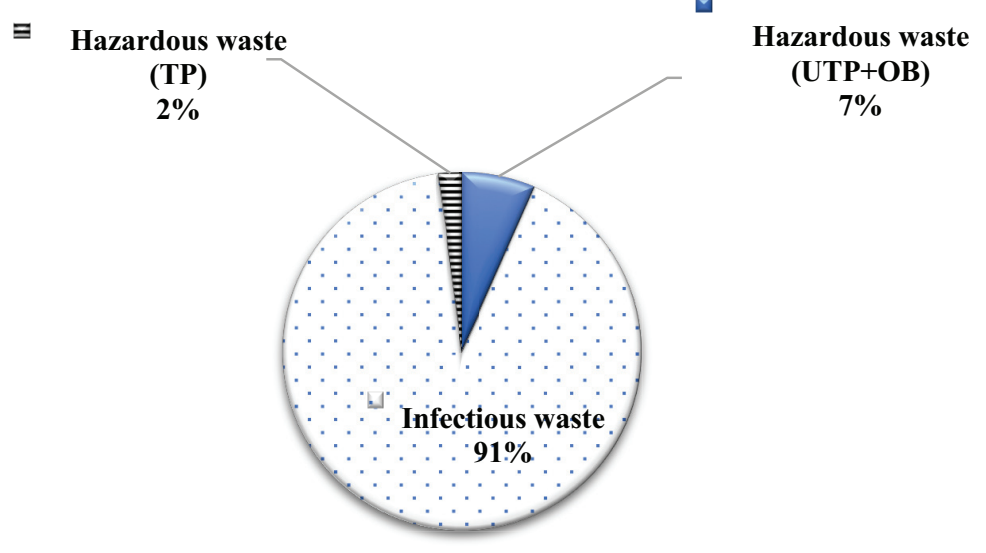

$\square$ Hazardous waste (UTP+OB) $\square$ Infectious waste $\Xi$ Hazardous waste (TP)

Figure 4: Percentage composition of hazardous waste. 
inside a plastic bin with a lid and sometimes there was no bag which did not meet the guideline standards. However, the guideline specifies a red bag for hazardous materials. In another study, some areas used yellow or red bags [1].

Infectious waste materials from treated patients, except sharp waste, were put in red plastic bags inside a plastic or stainless-steel bin. Moreover, some countries used yellow bags to keep infectious waste $[11,8,5,9]$. Sharp waste materials were put into red or yellow sharps bin or puncture proof container without a cover that was similar to a report by Mohamed et al. [1] that used a yellow puncture proof container to keep sharp waste materials but it had a cover. On the other hand, the report by Manga et al. [9] described a sharp bin used in some health care facilities in Cameroon. They used glass, plastic or cardboard boxes to keep sharp waste and some facilities used a special container [9]. In addition, Al-Khatib et al. [12] reported on disposal packages at health care centers in the West Bank-Palestinian Territory that used sharp bins that were plastic boxes, carton boxes, metal boxes, special bags (yellow leak-proof plastic containers sometimes with the international symbol of infectious substance), and normal bags (light plastic, easily broken, not leak-proof) [12].

Finally, the hazardous waste from treated patients, especially, expired drugs (liquids, pills, and capsules) were kept in a plastic basket without a bag inside. However, as reported by others, a brown plastic bag or container was used $[8,13,10]$. The details are shown in Table 4.

In addition, all solid waste materials in the government health centers were collected from bins and moved to a temporary waste storage point by a staff member at each government health center every day, and waited for transfer to an off-site disposal center. It was found that the waste handlers at the government health centers wore personal protective equipment while working. They wore a medical cap, health mask, gloves, eye goggles, plastic apron, and rubber boots according to the Ministerial Regulation on General Waste Management B.E. 2560 (2017). This was similar to a report by Mohamed et al. that described the personal protective equipment used in large public

Table 4: Waste storage and container.

\begin{tabular}{|c|c|c|}
\hline Waste type & Type of container (bag/bin) & $\begin{array}{l}\text { Color used by } \\
\text { GHCs (bag) }\end{array}$ \\
\hline \multicolumn{3}{|l|}{ 1. Non-hazardous waste } \\
\hline 1.1 General waste & $\begin{array}{l}\text { Plastic bag inside a stainless steel or } \\
\text { plastic bin }\end{array}$ & Black \\
\hline 1.2 Domestic waste & Plastic or rubber bin & Black or translucent \\
\hline \multicolumn{3}{|l|}{ 2. Hazardous waste } \\
\hline 2.1 Hazardous waste & $\begin{array}{l}\text { Plastic bag inside a plastic bin or no } \\
\text { plastic bag inside the bin }\end{array}$ & Black \\
\hline \multirow[t]{2}{*}{ 2.2 Infectious waste } & $\begin{array}{l}\text { Plastic bag inside a plastic or stain- } \\
\text { less steel bin }\end{array}$ & Red \\
\hline & $\begin{array}{l}\text { Sharps bin or puncture proof con- } \\
\text { tainer without cover }\end{array}$ & Red or yellow \\
\hline \multirow[t]{2}{*}{ 2.3 Hazardous waste } & $\begin{array}{l}\text { No bag inside plastic basket (put } \\
\text { only expired drugs) }\end{array}$ & - \\
\hline & Plastic bag inside a plastic bin & White \\
\hline
\end{tabular}


facilities in the Kingdom of Bahrain [1]. However, it was found in Cameroon that a group of workers lacked the use of personal protective clothing and equipment [9].

\subsection{Waste collection, transportation, and disposal}

Waste collection, transportation and disposal of solid waste at the government health centers were controlled by professional registered nurses, an experienced technical nurse, and a worker from a district hospital. The overall procedure of waste collection, transportation, and disposal can be described as two procedures.

1. On-site waste collection: Initially, all solid waste materials from the government health centers were kept and collected by types at temporary waste storage points inside the government health center (Fig. 5). The solid waste materials were collected by a waste handler every day. Each government health center separated the waste into two major types at two separate storage points that were designated as non-hazardous waste and hazardous waste and the staff personnel wore suitable suits while working.

2. Off-site waste transportation and disposal: The non-hazardous waste (general waste and domestic waste) and hazardous waste (HW from OBs and UTPs) in each government health center were mixed and collected by 2-3 employees of sub-administrative organizations (transport workers) and the waste was moved at unspecified times for disposal (Fig. 6). The waste materials were transported by compact garbage truck (municipality truck) and disposed at an open dump outside the vicinity of the government health centers which was the same as in Cameroon and Botswana [9, 10]. On the other hand, in India and West Bank-Palestinian Territory they employed the open burning method to dispose the waste $[11,12]$. The most common methods of disposal of solid waste materials from the health centers in term of health care waste are the open dump and landfill methods. Health care waste which was nonclinical waste was placed landfills without disinfection to kill micro-organisms [10].

However, in this study, the open dump method is uncontrolled and has poorly designed dump sites that conflicted with the Ministerial Regulation on General Waste Management

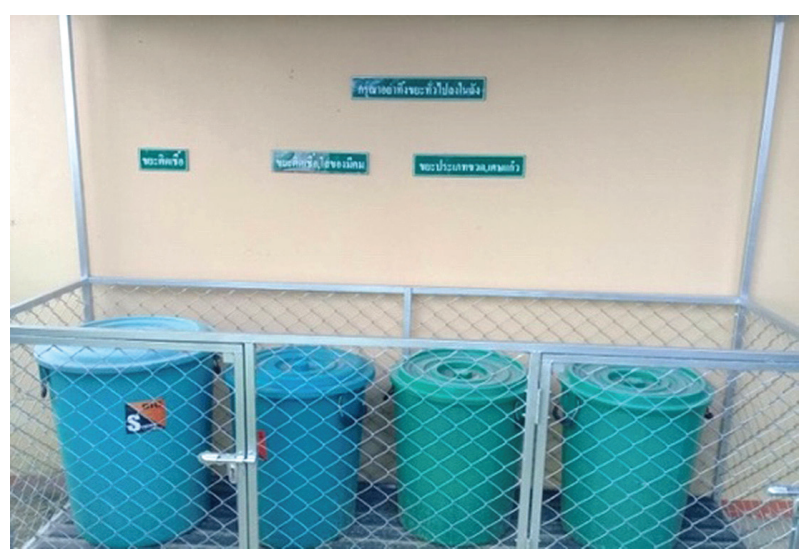

Figure 5: Waste storage point of infectious waste. 


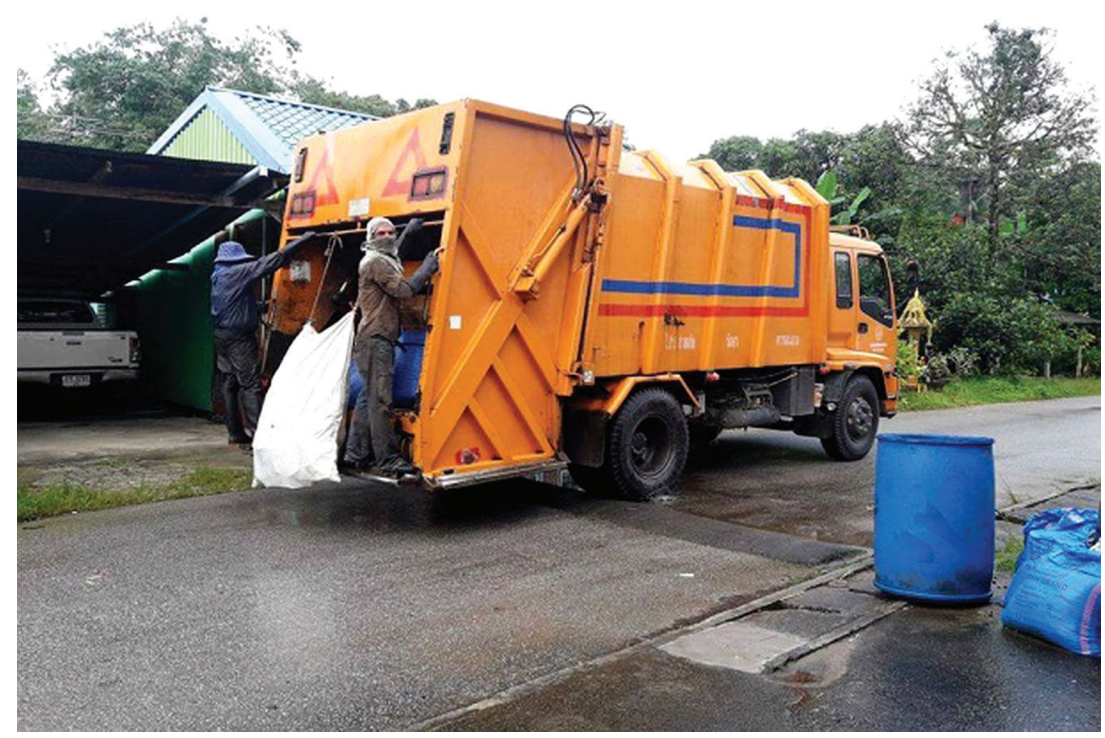

Figure 6: Transport worker of sub-administrative organization and compact garbage truck.

B.E. 2560 (2017) that specifically relates to non-hazardous waste and hazardous waste materials which need to be separated at the source and must be sorted into at least 4 types (i.e., general, hazardous, recyclable and biodegradable waste) and placed into strong and durable plastic bags or containers and enclosed with rope or a lid before removal to a proper disposal site (i.e. sanitary landfill, waste incineration, compost or biogas) or others that depend on suitable methods determined by the employees of the sub-administrative offices or cooperation between the government, sub-administrative offices, and private companies [14].

In case a sanitary landfill minimizes the risk and reduces the hazard of contaminated waste and preserves the environment and human health [10]. However, an open dump without an adequate design and considerations to guarantee protection of the environment may pose a serious threat to the health of the community [9]. The leachates from an open dump or surface runoffs may contain toxic chemicals and pathogens that lead to contaminated soil and water [15] which attracts insects, rodents and other small animals [8]. An uncontrolled open dump is the most common waste disposal method in developing countries [16].

In addition, hazardous waste (infectious waste) materials were transported by pickup truck by workers from a district hospital once a week. This also conflicted with the Ministerial Regulation on the Disposal of Infectious Waste B.E. 2545 (2002) because the vehicle used to transfer and transport the infectious waste must have an unencumbered structure with an inner wall made from durable material that is easy to clean and does not leak [17]. The pickup truck used in this process was an unsuitable vehicle that could leak or spill the waste during transfer or transport which would contaminate the environment and present a health hazard to the waste workers [10]. The waste materials were then kept in a waste storage room in a hospital and waited for transport by a company authorized by the government or licensed (same as waste transport in the Kingdom of Bahrain) to use the incineration method in central Thailand. This method is used also in the Kingdom of Bahrain, Cameroon, and Botswana $[1,9,10]$. The most common treatment technology for 
this waste is incineration. However, in recent years the shortcomings of incineration have been largely realized and there is no agreement on what is environmentally safe [18].

Hazardous waste (expired drugs) materials were kept once a week by workers from a district hospital (same as infectious waste) but stored at the hospital for return to the suppliers or manufactures. The transport workers who transferred these waste materials wore unsuitable personal protection equipment while working that was not in accordance with the guidelines and standards of Thailand. These results were similar to reports by Mmereki et al. and Manga et al. that described groups of workers that lacked the use of personal protective clothing and equipment while working in Botswana and Cameroon, respectively $[9,10]$.

Overall, the proportion of non-hazardous waste was greater than hazardous waste at the government health centers because the source of non-hazardous waste was from two main sources: (1) unpacked and unwrapped medical supplies used to treat patients and (2) paper, plastic containers/bags and biodegradable waste from the untreated patients. Most of the waste was not segregated and sometimes the waste was mixed with hazardous waste (i.e. aerosol spray cans, desiccants, batteries, electric light bulbs). In fact, many kinds of waste can be separated for reuse or recycled such as paper, plastic bags/containers from the office buildings and packages/wrappings of medical supplies. Sorting the waste at the source can reduce the amount of waste for disposal and increase the income for the hospital from the sale of certain waste products. In addition, if they separated the hazardous waste from of non-hazardous (nonrecyclable waste materials), the waste could be easily classified for suitable final disposal methods such as incineration (waste to energy) and sanitary landfill. Biodegradable waste, such as food, fruits, and vegetables can be processed into compost.

Hazardous waste, especially expired drugs, other toxic chemicals, and infectious waste materials on-site and off-site, must be placed in controlled waste storage (bag/container). Hazardous waste materials must not be placed in a basket without a bag but placed in a plastic bag and enclosed with a rope. The container for infectious waste must be a red plastic bag and the short messages 'Infectious waste', 'Do not reuse', and 'Do not open' must appear on the container according to the Ministerial Regulation on the Disposal of Infectious Waste B.E. 2545 (2002) [17]. Furthermore, this study found that waste collection, waste transportation of infectious waste, and personal protection of the waste workers and off-site vehicles were unsuitable and incorrect according to the guideline [17]. The waste workers need to wear personal protection equipment that consists of a face mask, gloves (rubber/household gloves or heavy-duty gloves), medical cap, eye goggles, plastic apron, and rubber industrial boots. The vehicle must be an unencumbered structure with an inner wall made from durable material, easy to clean, and does not leak to prevent waste distribution. Moreover, the waste worker must be trained and have knowledge on the handling of infectious waste and get a health check. Thus, the government health centers must strictly manage, protect, and control the distribution of waste to reduce the volume of toxic chemicals and pathogenic waste into the environment.

The management of solid waste from the government health centers needs improvements in many issues that include: (1) strict separation of solid waste materials that are either nonhazardous waste (general waste and domestic waste) or hazardous waste (HW from OBs/ UTPs); (2) personal protective equipment of the waste workers; (3) vehicle for infectious waste transportation; and (4) disposal method for non-hazardous waste materials according to the regulations and guidelines. In addition, the government health centers need to use other options to reduce solid waste within the government health centers such as adequate training on solid waste management, waste reduction at the source, and reuse and recycling of nonhazardous waste to prevent pollution instead of disposal at the end of the pipe. 


\section{CONCLUSIONS}

All services and activities at the government health centers produce solid waste materials. More specifically, these materials come from treated and untreated patients and office buildings. The solid waste materials were classified into two major groups that included non-hazardous waste and hazardous waste materials. Non-hazardous waste was comprised of general and domestic waste from treated patients, office buildings and untreated patients. Hazardous waste was separated into three types: (1) hazardous waste from office buildings and untreated patients; (2) infectious waste; and (3) hazardous waste from treated patients. In the group of non-hazardous waste, the quantity of domestic waste was more than general waste. The amount of infectious waste was higher than hazardous waste from office buildings, untreated patients, and hazardous waste from treated patients. The containers for hazardous waste usually used incorrect bag colors and sometimes there was no bag. Furthermore, the personal protective equipment of the waste workers who handled infectious waste while working was incorrect. Unsuitable clothing and vehicles were used in the transport of infectious waste which was in conflict with the guidelines. Overall, the practice of using an open dump for the disposal of non-hazardous materials that were mixed with hazardous waste from office buildings and untreated patients is unlawful according to the laws of Thailand. Therefore, it is necessary that the government health centers strictly practice the guidelines and comply with the standards set out by law to properly handle and dispose of all waste materials to reduce the effects of health care waste pollution on the environment.

\section{ACKNOWLEDGEMENTS}

The authors would like to thank Phuket Rajabhat University for their financial support for the registration and carfare.

\section{REFERENCES}

[1] Mohamed, L.F., Ebrahim, S.A. \& Thukair Al, A.A., Hazardous healthcare waste management in the Kingdom of Bahrain. Waste Management, 29(8), pp. 2404-2409, 2009. https://doi.org/10.1016/j.wasman.2009.02.015

[2] Elevate health center to health promotion hospitals, Thai Health Promotion Foundation. Online, http://www.thaihealth.or.th (accessed 14 June 2018).

[3] Safe management of waste from health-care activities. Online, http://apps.who.int/iris/ bitstream/handle/10665/85349/9789241548564_eng.pdf;jsessionid=A74F6584BC09D 92A5ADF7CF5FB36A386? sequence=1 (accessed 12 June 2018).

[4] Management of solid health-care waste at primary health-care centers: a decisionmaking guide. Online, http://www.who.int/water_sanitation_health/publications/manhcwm.pdf, (accessed 12 June 2018).

[5] Diaz, L.F., Eggerth, L.L., Enkhtsetseg, Sh. \& Savage, G.M., Characteristic of healthcare wastes. Waste management, 28(7), pp. 1219-1226, 2008.

[6] Puangmanee, S. \& Jearani, M., Solid waste management from a primary care unit. Proceedings of the $7^{\text {th }}$ National Conference, pp. 19-20, 2018.

[7] Puangmanee, S. \& Jearani, M., Health care waste management: a case study of Healthpromoting hospitals. WIT Transactions on Ecology and the Environment, Vol 231, WIT Press, 2018.

[8] Nemathaga, F., Maringa, S. \& Chimuka, L., Hospital solid waste management practices in Limpopo Province, South Africa: A case study of two hospitals. Waste Management, 28(7), pp. 1236-1245, 2008. https://doi.org/10.1016/j.wasman.2007.03.033 
[9] Manga, Veronica E., Forton, O.T., Mofor, L.A. \& Woodard, R. Health care waste management in Cameroon: A case study from the Southwestern Region. Resources, Conservation and Recycling, 57, pp. 108-116, 2011. https://doi.org/10.1016/j.resconrec.2011.10.002

[10] Mmereki, D., Baldwin, A., Li, B. \& Liu, M. Health care waste management in Botswana: storage, collection, treatment and disposal system. Journal of Material Cycles Waste Management, 19(1), pp. 351-365, 2017. https://doi.org/10.1007/s10163-015-0429-0

[11] Patil, A.D. \& Shekdar, A.V., Health-care waste management in India. Journal of Environmental Management, 63(2), pp. 211-220, 2001. https://doi.org/10.1006/ jema.2001.0453

[12] Al-Khatib, I. \& Sato, C., Solid health care waste management status at health care center in the West Bank-Palestinian Territory. Waste Management, 29, pp. 2398-2403, 2009. https://doi.org/10.1016/j.wasman.2009.03.014

[13] Abah, S.O. \& Ohimain, E.I., Health care waste management in Nigeria: A case study. Journal of Public Health and Epidemiology, 3(3), pp. 99-110, 2011.

[14] Ministerial Regulation General Waste Management B.E. 2560. Online, http://laws.anamai.moph.go.th/main.php?filename=2RLaws, 2017 (accessed 14 June 2018).

[15] Diaz, L.F., Savage, G.M. \& Eggert, L.L., Alternatives for the treatment and disposal of healthcare wastes in developing countries. Waste Management, 25, pp. 626-637, 2005. https://doi.org/10.1016/j.wasman.2005.01.005

[16] Eggen, T. Moeder, M. \& Arukwe, A., Municipal landfill leachates: a significant source for new and emerging pollutants. Science of Total Environment, 408(21), pp. 5147-5157, 2010. https://doi.org/10.1016/j.scitotenv.2010.07.049

[17] Ministerial Regulation Disposal of Infectious B.E. 2545. Online, http://laws.anamai. moph.go.th/main.php?filename=2RLaws, 2002 (accessed 14 June 2018).

[18] Prem Ananth, A., Prashanthini, V. \& Visvanathan, C., Healthcare waste management in Asia. Healthcare waste management in Asia. Waste management, 30(1), pp. 154-161, 2010. https://doi.org/10.1016/j.wasman.2009.07.018

[19] Phangnga Provincial Public Health Office, Village Information and Responsibilities of Public Health Facilities. Online, http://www.pngo.moph.go.th/pngo/index.php/122016-12-19-08-16-31/64-information-health-phangnga-5 (accessed 12 January 2017). 